\title{
Beyond Contagion of Violence: Passionate Love and Empathy in the Thought of René Girard and Max Scheler
}

\section{Bogumił Strączek ${ }^{1}$ (D)}

Accepted: 17 November 2021 / Published online: 7 December 2021

(c) The Author(s) 2021

\begin{abstract}
In his last book René Girard depicts apocalypse as disclosure of mimetic violence that is world-ending. He claims that in times of violent pandemic we are not called to fight for this world, but follow Christ in his withdrawal from the world. However, such an assertion creates serious theoretical and practical issues for the effort to heal interhuman relations from the virus of mimetic hostility. I argue for the importance of restoring a foundational distinction between passionate love and acquisitive mimetic desire from the forgotten regions of Girard's oeuvre. With Max Scheler's interpretation of Stendhal's concept of l'amour passion, I explore in each thinker a fundamental insight about possibilities of transforming violent contagion through empathy and loving commitment to the world. I conclude that respective "passive" and "active" approaches to the contagion of mimetic rivalry and violence are necessary and equally valuable.
\end{abstract}

Keywords Apocalypse $\cdot$ Empathy $\cdot$ Girard $\cdot$ Mimetic desire $\cdot$ Scheler $\cdot$ Violence

\section{Introduction}

René Girard's last book Battling to the end (2010) represents an intriguing and provoking attempt to make sense of what might be called "apocalyptic realism". While religious fundamentalists mythologize Book of Revelation by reading it as an announcement of God's violent triumph over evil and corrupted creation, Girard considers apocalypse as disclosure of world-devastating violence that comes from people, and not from a God. In addition, he rejects those approaches that interpreted apocalyptic texts as mere "fantasy" or "metaphor" without correspondence to historical reality. He states that after the French Revolution and Napoleonic total

Bogumił Strączek

bogumil.straczek@ignatianum.edu.pl

1 Jesuit University Ignatianum in Krakow, Krakow, Poland 
mobilization, when wars have become particularly vulnerable to extreme escalation, we witness history moving toward rapid mimetic violence that can no longer be checked. In one of the opening paragraphs of the book Girard writes: "Today, violence has been unleashed across the whole world, creating what the apocalyptic texts predicted: confusion between disasters caused by nature and those caused by humans, between the natural and the man-made: global warming and rising waters are no longer metaphors today" (Girard \& Chantre, 2010: x).

Girard's apocalyptic realism is consistent throughout his work. His is not any kind of "enlightened doomsaying" that focuses on continually postponing apocalypse into a future where it does not occur (see Dupuy, 2002). As a logical result, Girard argues consistently that we should "abandon all optimism", and acknowledge the fact that "the apocalypse has begun" (Girard \& Chantre, 2010: 132-210). But what are we to make of this "Girardian truth"? How are we to translate the revelation of apocalyptic texts into contemporary ethical concerns? In other words, what are the practical consequences of accepting apocalypse? Girard does not avoid an answer. In the dark times of the world's night, we are not called to fight for this world, but to withdraw from the world. We shall do so, since there is a real abyss between the kingdom of God, that "is not of this world" (J 18: 36) and the worldly kingdom of violence. These two kingdoms "cannot communicate with one another" (Girard et al., 1987: 199). However, such an assertion creates a serious theoretical and practical issue for the effort to heal interhuman relations from the virus of mimetic hostility.

I trace Girard's late pessimism back to his move toward mimetic reductionism, resulting in totalization of mimetic desire in his work. Girard totalizes desire by insisting that it is inherently mimetic, while at the same time he acknowledges that there is also non-mimetic desire (see Di Blasi, 2015: 46). Since Girard obscured the latter it is often assumed that his concept of desire as it occurs in his first book aligns with his further thought (see Scubla, 2016: 273). As a matter of fact, in Deceit, Desire and the Novel (1965) mimetic desire is considered a derived and secondary phenomenon. Beyond mimetic desire and imitation, primary and vital passions exist, such as the love that parents have for their children or the experience of truly loving sexual intercourse. Neither can be interpreted in mimetic fashion (Girard \& Treguer, 2014: 11f.-12). This insight Girard owes to Stendhal. However, with the subsequent development of mimetic anthropology towards an all-encompassing theory of conflict and violence, the aptly grasped phenomenological difference between mimetic desire and vital passions is neglected. Girard never denied the distinction, but he focused so one-sidedly on the scientific exploration of negative effects of mimetic desire that he had difficulty in drawing out the positive implications of passionate human love and empathy as a counter-balance to acquisitive desire and imitative violence.

I argue for the importance of restoring the Stendhalian sense of passionate love from the forgotten regions of Girard's oeuvre. Such a move provides resources to continue building where Girard left off and to strengthen his intellectual edifice in the process. While in Deceit, Desire and the Novel Girard focused on mimetic desire as tending toward nothingness and death, he was inattentive to the crucial feature of l'amour passion as tending toward life. Max Scheler is significant here as he links 
Stendhal's idea of passionate love with a feeling of the cosmo-vital unity of all living beings. However, as Scheler explains: “[m]an's point of entry into identification with the life of the cosmos lies where that life is nearest and in closest affinity to his own, namely in another man" (Scheler, 2008: 108). Our relationships with others are crucial to experience this mysterious unity of life. According to Scheler it is St Francis who uplifted passionate love for the world and creation into the highness of Christian love for God and neighbour, while at the same time enriching agapic love by opening it to a deeper experience of ordinary life. Recovering awareness of a foundational distinction between passionate love and acquisitive desire is also important for another reason. It undergirds the respective "passive" and "active" approaches to the contagion of mimetic rivalry and violence, each of which is valuable.

\section{Contagion and Apocalypse}

In much of his work, René Girard proposed that scapegoating, even in a subtle form, is at the root of all cultures and civilizations. It is an effective way of resolving conflicts and reducing social violence. He explains this mechanism by referring to the human pre-rational tendency to imitate each other's desires. For when two people strive to appropriate the same object, they come into conflict. As a result, a complex entanglement with the other takes place. The rivalry permeates personality structures so much that its foundation is not an object as such, but rather a mysterious quality, called "being", that is constantly ascribed to the person of the rival. The subject desires not only to "have" what the other has, but above all to "be" like the other, to realize a certain mode of existence (which is why Girard often says that mimetic desire is "metaphysical" at the same time) (Girard, 1965: 55). This is the generative and regenerative cause of the continual rebirth of violence in interpersonal relations.

Additionally, mimetic rivalry absorbs not only individuals but also whole communities. It can spread like a plague reaching an entire community. The intriguing question then arises: how can society overcome this self-propelled crisis? Girard argues that the solution is provided by "mimetism itself". For when violent contagion spreads so much that it begins to threaten the survival of the community, then, through a self-regulating mechanism, the hostility of the community is mimetically directed against a random victim whose murder will relieve tension and remove the risk of an "apocalypse". Previously, identified as a cause of the crisis and all evil, the scapegoat is then sacralised as a source of peace and collective unity (see Girard, 1977). History confirms this truth. The same murderous forces have always shown themselves in archaic sacrificial rituals, persecution of witches, civil wars, and genocides (see Girard, 1986). Without genocide and scapegoats, the establishment of permanent social structures in many regimes, but also in democratic and liberal countries, would be impossible (see Dumouchel, 2015).

However, the impact of the above-described mechanism is becoming weaker. As scapegoating is driven by the force of unfair accusations and, once the victim's innocence is revealed, its effectiveness as an instrument of social control significantly decreases. In fact, the process of rehabilitation of the victims itself has been going on for a long time, and it achieves its globalised and secular form in contemporary 
humanitarianism. Girard traces the religious sources of this entire process through his discovery that under the pressure of the Christian revelation the old sacrificial order is gradually disintegrating. Christianity is also based on a victim-Crucified Jesus-but the victim is presented as innocent and his murder is considered unjust (see Girard et al., 1987). The Passion of Christ thus lays the foundations for the post-sacrificial world. However, paradoxically, it was precisely due to the increasing protectionism of the victims that humanity became capable of complete selfdestruction for the first time in its long history. Evangelical revelation, by depriving us of a mechanism to limit violence, in effect, triggered the expansion of violence on a global scale. In this way, Christianity has become a source of instability in a globalised world that is consistently heading towards the apocalypse. Even if incidents of sacrificial violence can still be observed, at the present time every sacrifice suffered is completely in vain. It is so because all its conciliatory creativity has been lost. Thus, violence, which in pre-modern societies was capable of evoking an illusory sense of unity, now "produces anything but itself" (Girard \& Chantre, 2010: x).

So if we can no longer base our collective beliefs on the sacrificial institution, then the future presents us with a difficult choice: "We have to destroy one another or love one another" (Girard \& Chantre, 2010: 49). It is an alternative that accepts no half measures. Incomplete conversion will open up new horizons for the extreme escalation of violence, that today becomes more and more unpredictable and immune to resistance. Are we capable of making such a radical conversion from the order of violence toward the order of charity? In Battling to the End Girard does not delude himself. As an "apocalyptic realist" he fears that "humanity (...) will prefer to destroy itself” (Girard \& Chantre, 2010: 49). Thus, he abandons his earlier observations of Things Hidden, according to which the doctrine of the Kingdom of God, announced by Christ in the sermon on the Mount, is realistic, to be adopted here and now (see Girard et al., 1987: 191f.). As he states in a later interview, Christianity is not a religion that promises God's Kingdom on earth. While it promotes a culture of charity, it does not promise its absolute victory over the culture of violence. "Fundamentally, it is a religion that announces the world to come; it is not about fighting for this world" (Doran and Girard, 2008: 26).

\section{Empathy or Withdrawal from the World}

It should be emphasised that the pessimism in the late works of Girard is not the result of some preconceived anthropological or historical determinism, but the result of careful observation of the current situation of the world. We have not so much failed to accept the truth stemming from the biblical demystification-we have been living in the hyper-anti-sacrificial world since modernity rather, we have failed to draw the full consequences from this teaching. In other words, "We are not Christian enough" (Girard \& Chantre, 2010: x). Therefore, Girard understands that the self-destruction of humanity through unlimited violence is a matter of choice, not blind necessity. As he writes: "The future of the world is out of our control, and yet it is in our hands: this is something to think about" (Girard \& Chantre, 2010: 49). Our responsibility is greater than ever, and it is, therefore, urgent to develop new 
strategies to deal with unpredictable violence. In the face of the powerlessness of politics and militarism fighting for peace, "a new ethic is required" (Girard \& Chantre, 2010: 24).

What does Girard mean when he talks about the need for "a new ethic"? In fact, he has never been overly specific when it comes to ethical issues. Clearly, he wished to avoid ready-made solutions to deal with the current crisis. Defining his anthropology as an objective science about human beings, he was well aware of the fact that science cannot act simultaneously as ethics. Its purpose is only to explain the mechanisms governing (individual and collective) human behaviour and to point out their consequences. However, in Battling to the End Girard-probably following the suggestion of his interlocutor-is considering the possibility of moving from the order of violence towards the order of charity. The latter concept acquires a distinct Pascalian sense, as it is considered in the context of a metaphor; the transition from the "order of bodies" to the "order of charity" (Girard \& Chantre, 2010: 134). Pascal talked about the distance that must be kept from a painting in order to see it properly. ${ }^{1}$ Perspective is established in this way in the art of painting, while in matters of morality it is the "exact point" from which an empathic identification with another person should be practiced. Therefore, in interpersonal relationships, it is necessary to maintain an appropriate distance, because "[e]xcessive empathy is mimetic, but excessive indifference just as much" (Girard \& Chantre, 2010: 134).

Empathy is a form of positive imitation that is not aimed at acquiring the being of the other as in mimetic desire, but at identifying with the Other. Identification means seeing in the Other a human being just like me, in the sense that we are both aroused by the same violent mimetism. In this way, by seeing the Other as a victim of my own mimetism, I allow him to reveal himself in "the vulnerability of his face" (Girard \& Chantre, 2010: 100). This form of identification requires the Other with whom one can empathise and identify. Therefore, whereas mimetism always leads to identity between rivals, empathy preserves difference and a sense of distance. Thus, without appropriating the being of a neighbour or renouncing our own existence, empathy is caring for another person without violating their "sphere of privacy". One could also say that through empathy, the relationship between persons both transcends and maintains the boundaries of intimacy. ${ }^{2}$

Girard seems to agree with the suggestion made by Benoît Chantre that identification with the other must be understood as a means of correcting human mimetic inclinations: "Mimetism brings me too close to or too far from the other. Identification makes it possible to see the other from the right distance" (Girard \& Chantre, 2010: 134). The problem, however, is that this entire identification process is constantly thwarted by mimetism that humans are not quite able to adequately manage. In daily life, we seem always too far away or too close, breaking the basic principle of the ethics of distance. Only Christ allows people to keep an appropriate distance between them.

\footnotetext{
1 "So with pictures seen from too far or too near; there is but one exact point which is the true place where from to look at them: the rest are too near, too far, too high, or too low. Perspective determines that point in the art of painting. But who shall determine it in truth and morality?" (Pascal et al., 1910: 126).

2 More on the subject of empathy in the mimetic theory; see Astell (2004).
} 
Following Christ allows us to get out of the spiral of mimetism and keep a proper distance toward others (Girard \& Chantre, 2010: 133f.).

In his earlier works, Girard repeatedly referred to imitatio Christi, but only in Battling to the End can one find the culmination of this theme. First of all, he emphasises that if such (synonymous) concepts as "positive mimesis", "imitatio Christi" or "innermost mediation" refer to the imitation of the divine ideal, then their content proves that the realisation of this ideal cannot go hand in hand with the messianic ambition to save the world. The story of original sin—as it is read by the Girardian theologian Raymund Schwager in his Banished from Eden-warns against such a temptation to equal God. This temptation is not always directly exposed and can be easily hidden behind a facade of pious or high ethical demands (Schwager, 2006: 206). Therefore, Girard states that, following Christ, one should at the same time get rid of the illusions of triumphant moral heroism and accept the truth about the limited possibilities of human influence on the course of history. While in his earlier works Girard pointed to Christ crucified as a model who renounced violence to his death, in Battling to the End he points to two other figures of kenosis: silence and withdrawal from the world: "The Incarnation was the only means available to humanity to face God's very salubrious silence: Christ questioned that silence on the cross, and then he himself imitated his Father's withdrawal by joining him on the morning of his Resurrection. (...) He withdraws at the very point when he could dominate. We in turn are thus required to experience the peril of the absence of God, the modern experience par excellence, because it is the time of sacrificial temptation, the possible regression to extremes, but it is also a redemptive experience. To imitate Christ is refuse to impose oneself as a model and is always efface oneself before others. To imitate Christ is to do everything to avoid being imitated" (Girard \& Chantre, 2010: 122).

Girard points to Hölderlin as the one who understood that the way out of the mimetic madness of modernity can only lead through imitating Christ in the "withdrawal relationship" (Girard \& Chantre, 2010: 123). The poet, who for almost forty years isolated himself from the outside world, staying in the tower in Tübingen to the end of his life, finds peace and a mystical relationship to the absence of God and only in solitude. Experiencing the preponderance of darkness over light, Hölderlin leaves the "mimetic giddiness of worldly existence" (Girard \& Chantre, 2010: 123), and understands in this move of detachment the path to personal salvation. For Girard, the poet's interior exile has a deeply Christian sense. He concludes that "Hölderlin was deeply Christian or rather became more and more so as he withdrew from the world" (Girard \& Chantre, 2010: 123). Therefore, we should also "take the measure of that silence" and "measure up to it" (Girard \& Chantre, 2010: 44f.). But does Höderlin's solitude point the way in a time of the night of the world? Does his withdrawal from the world set a proper distance (not too far not too close) to the other?

\section{Return to the World}

Girard's turn toward mystical quietism has deep theological meaning. However, one cannot miss its practical implications and significant issues for any effort to map a path from the (dis)order of violence toward the order of charity. When Girard 
concludes that the right distance, the right point of reference can only be established by Christ, and then adds that the aspect of divine that has to be imitated is God's silence and Christ's withdrawal from the world, he arrives at a paradoxical conclusion: the right distance to practice empathic identification is achieved when there is no longer any relationship with the other or the world. The withdrawal relationship that Girard describes with reference to Höderlin is an attempt to avoid any horizontal relationship with another human being. It is characterized by loneliness and the effacement of oneself before others, in the heroic effort to be no longer imitated (Girard \& Chantre, 2010: 134).

We must ask: is such keeping others at a distance the proper therapy for our addiction to mimetism? Can we find a different culture and ethics of interpersonal relationships, one in which our indifference is replaced by charitable identification with the victims suffering within the world? Wolfgang Palaver is undoubtedly right when he writes that since all forms of violence begin at the level of interpersonal relations, it means that any attempt to overcome them should also begin with a transformation of our actions at this fundamental level (Palaver, 2013: 294). Girard is undoubtedly aware of this when he writes that "[f]oundation is never a solitary action; it is always done with others" and "[o]nly ethical relations could still found something" (Girard \& Chantre, 2010: 23). Ultimately, however, he himself refuses to describe the conditions of possibility of healing these horizontal relationships within temporal community and within the immanence of everyday events. Instead, he proposes contemplative detachment and a transcendental relationship with God's absence.

The German mystic and preacher Dietrich Bonhoeffer testifies to a different attitude in the face of the night of the world. In the months before his execution by the Nazis, he experienced the same anxiety that plagued Hölderlin. Being a direct witness and a victim of the atrocities of war and Nazism in a solitary cell, he wrote of God's silence and absence. This experience of the "absence of God," which Girard described as par excellence the modern experience, showed him the most pressing dilemma of Christianity: "In what way are we religionless-secular Christians, in what way are we the ex-klesia, those who are called forth, not regarding ourselves from a religious point of view as specially favoured, but rather as belonging wholly to the world?" (Bonhoeffer, 1971: 279).

Bonhoeffer's answer to this dilemma is not mystical quietism or world-denying spiritualism, but the revalorization of this-wordliness and our commitment to it. He writes: "I have come to understand more and more the profound this-worldliness of Christianity. (...) I don't mean the shallow and banal this-worldliness of the enlightened, the busy, the comfortable, or the lascivious, but the profound this-worldliness, characterized by discipline and constant knowledge of death and resurrection. (...) By this-worldliness I mean living unreservedly in life's duties, problems, successes, experiences and perplexities. In so doing we throw ourselves completely into the arms of God, taking seriously, not our own sufferings, but those of God in the world—watching with Christ in Gethsemane (Bonhoeffer, 1971: 369f.).

On the threshold of the experience of withdrawal from the world and death, Bonhoeffer emphasised that the powerless God gives us strength, making us capable of affirming life, resisting evil and leaving the inner sense of guilt towards community and positive reciprocity. He explained the importance of preaching the Word of God 
in order to open up space for our shared responsibility and communication. Even in the darkest moments of experiencing God's absence in the world, in times of persecution, concentration camps, or fundamentalist terrorism, Christians are called to affirm life because the risen Christ by no means gives us an invitation to withdraw from this world. In his comment to this passage, Richard Kearney explains: "Resurrection is to be understood accordingly as the event that returns us to the world, to the secula seculorum, so that we may live more abundantly (Kearney, 2010: 68). Girard seems to underestimate this aspect of loving and active engagement with the world.

Paradoxically, the more faith in the grace of salvation can be felt in his later works, which is undoubtedly the strongest in Battling to the End, the more faith in human beings and our ability to make the right choices deteriorates. Characteristically, however, Girard's disbelief in humanity appears where faith in God becomes more and more detached from the community and closed in silent isolation. With this radicalization of the opposition of the transcendence of the Kingdom of God and the immanence of the kingdom of violence, the threat of human being alienation and the closure to the problems of this world can only increase.

\section{Beyond Mimetic Contagion}

Girard's anthropological pessimism creates a serious practical issue for the effort to heal interhuman relations: if an obstacle of silence and sadness exists between me and the other, we drift apart and become strangers rather than neighbours. In light of this, it is necessary to rethink interpersonal relationships in order to regain the lost distance. To do so, we are not required to give up the entire legacy of the mimetic theory. Instead, we must return to Girard's early reflections and find in his Deceit, Desire and the Novel discussion of the key themes of desire and the passions that distinguish this work from his other books.

In Violence and the Sacred and subsequent writings, Girard repeatedly states that there is no escape from mimetic desire that is inherently mimetic. However, in his earlier Deceit, Desire and the Novel, Girard treats mimetic desire as a secondary phenomenon in relation to more primal passions. Although he describes mimetic desire as "metaphysical", it has no ontological grounding: rather, it emerges as the result of particular historical coincidences (Holzhey, 2015: 238). The spread of metaphysical desire in the modern era is shown here as social contagion that invades the "vital centres of individual" and "infects the most intimate parts of being"(Girard, 1965: 43). This ontological sickness causes a whole range of negative consequences-from the internal breakdown of subjectivity, disturbances in interpersonal relations, and the individual's conflict with himself and the world, to uncontrolled, almost apocalyptic violence. However, earlier Girard still believed that there was an effective cure for the disease, but the therapy could not be successful without the active involvement of the patient. Here it presupposes a creative act of conversion, preceded by renunciation of metaphysical desire. Only through such renunciation can our vital centre regain order and harmony, and any negative effect of metaphysical desire can be replaced by an opposite effect: "Deception gives way to truth, 
anguish to remembrance, agitation to repose, hatred to love, humiliation to humility, mediated desire to autonomy, deviated transcendency to vertical transcendency" (Girard, 1965: 294).

Girard states that not every conversion results in the same practical consequences, and therefore "its effects cannot be expressed either in terms of absolute solitude or in terms of a return to the world" (Girard, 1965: 295). He further adds that this creative renunciation entails "reconciliation between the individual and the world, between man and the sacred" (Girard, 1965: 308). So what does Girard imply when he says that a true conversion always implies "renouncing metaphysical desire" and what kind of "reconciliation" does he suggest here? Does he imply that there is a non-metaphysical and authentic desire that open space to non-violent commitment to the world and with others?

Any doubts are dispelled by his reading of Stendhal, who in his novels uses precisely such a contrast between metaphysical desire and authentic passion. The writer introduces the the vaniteux to the stage - a vain person who is unable "to draw desires from his own resources" and "he must borrow them from others", and contrasts him with a passionate man who "is distinguished by his emotional autonomy, by the spontaneity of his desires, by his absolute indifference to the opinion of Others" (Girard, 1965: 6). A vain man is a slave to metaphysical desire because he is subject to the almost "organic falsehood"3 that he is a unique and unrepeatable individual. In fact, his life is wholly determined by imitating others. A passionate person in turn is synonymous with autonomous subjectivity because "he draws the strength of his desire from within himself and not from others" (Girard, 1965: 19). But Girard is not satisfied with limiting passion to autonomous desire and points to its other features. Passion is an emotional experience, based on a "perfect harmony between reason, will and sensitivity" (Girard, 1965: 24), it is a special type of an affirmative approach to the world and to other people, which "is always accompanied by respect in Corneille's sense of the word" (Girard, 1965: 19). It is also authentic religiosity, perhaps even "superstitious" in its simplicity, and at the same time, it is nobility in the spiritual sense.

The metaphor of painting and distance between the Self and the Other appears here as it appears in Battling to the end, but this time in the context of the moral and aesthetic difference between a romantic writer and a novelist. The former is "a prisoner of the Manichean opposition between Self and Others", who "like the modern painter, paints in two dimensions". In his image "absolute exteriority" of the other is opposed to "absolute interiority" of the Self. Unable to overcome his self-centredness the romantic writer cannot "reach the Other". He is unable to see the other from the right distance because he sees only himself. The novelist-Stendhal himself-rises above the romantic's narrow perspective which allows him to cross "the barrier between the Self and the Other". The testimony of that crossing "is recorded in the novel itself in the form of a reconciliation between hero and the world". This "novelistic reconciliation" is a "synthesis of introspection and observation" which "enables the novelist to view his characters from different perspectives and, with

\footnotetext{
${ }^{3}$ This term Girard takes from Scheler.
} 
the third dimension, give them true freedom and motion" (Girard, 1965: 146). For Stendhal this third novelistic dimension is attainable through passion since only "the lightning flashes of passion illuminate the shadows of vanity" (Girard, 1965: 150).

Stendhal's illumination-as Girard calls this passionate existence "beyond the metaphysical desire"-opens a new perspective for an individual to discover a man like himself in the Other. Consequently, the relationship between the self and the intermediary is re-established. Girard, however, does not fully explain what really turns metaphysical desire into true passion. He only mentions enigmatically-referring to Jean Prevost - that in all of Stendhal's great novels it begins with silence. But what is happening at this moment of silence? What is the cause of conversion that allows us to find a right distance - the third novelistic dimension? From what resources (immanent or transcendent) does this transformation draw its strength? Girard leaves these questions unanswered, remaining faithful to the letter of Stendhal's texts. All the internal transformations of the Stendhal's protagonists take place somewhere in the darkness of a mystery. It seems that some strange, mystical breath pulsates at the very heart of Stendhal's passion.

\section{Passionate Love and Other Forms of Sympathy}

Girard's reading of Stendhal brings up two essential points which help us avoid the paradoxes present in Battling to the End. Firstly, early analyses of desire show imitation as a secondary phenomenon relative to more primitive and vital passion, and that conversion assumes restoration of the original order in the most intimate areas of human life. This intimacy consequently allows us to restore nonviolent reciprocity. Secondly, this conversion-being the consequence of creative renunciation of metaphysical desire-does not necessarily result in "withdrawal from the world," but rather "reconciliation of the individual with the world", and consequently, the recovery of the proper distance between the Self and the Other. In later works, both elements are obscured by considerations concerning conflict-generating mimesis and the instability of interpersonal relationships; and additionally, the Stendhalian sense of passion is completely lost.

My basic argument is that Girard's own move in his later works did not take place without detriment to overall mimetic theory, which has consistently been characterized by the deprivation of tools to outline the conditions for the positive reciprocity in interpersonal relations. But Max Scheler-an equally attentive reader of Stendhal-showed that emotional identification, i.e., the vital sense of unity between individuals, lies at the heart of Stendhal's idea of l'amour passion. As a form of vital love that does not seek the appropriation of another being, but at the level of vital and mental functions, it constantly stimulates our desire towards constant flowering, multiplication and active participation in life. This is an understanding of passion that retains both its authentic and relational character.

Scheler cannot be ignored as being one of the first phenomenologists to most emphatically stress the relational, or even-as Girard would call it-interdividual nature of human existence (see Vandenberghe, 2008). This is particularly evident in his subsequent book, The Nature of Sympathy (2008). Here Scheler assumes that the 
intersubjective experience of the Other and society precedes egological experience in the structural and genetic order. While not using the concept of mimesis, Scheler describes our coexistence with others in a mimetic way. He writes: "Man [sic] tends, in the first instance, to live more in others than in himself; more in the community than in his own individual self" (Scheler, 2008: 247). From the first days of our life we learn to live in a world of other people because we are conditioned by mimesis. Following another great theoretician of imitation Theodor Lipps, Scheler terms this "emotional infection" (Scheler, 2008: 14-18). It is involuntary and unconscious copying of another person's affective states, which holds people together from the most undifferentiated crowd to the most organised societies. Like Girard's mimetic contagion, emotional infection produces in imitating people not only similar emotional states but also similar aims and intentions of action. Although it predisposes people to live in community, it involves a dangerous potential which manifests itself particularly in mass revolutionary movements and collective violence.

When emotional contagion reaches its most heightened and borderline form, that is when it covers not only feelings, but the being of the other and with its consequent feature of people imitating each other. In turn, this effects a transformation into a real sense of unity, or "emotional identification" (Einsfühlhen, Einsfühlung) (Scheler, 2008: 18-28). According to Scheler, in contrast to emotional contagion, the sense of unity is the most primitive form of empathy (understanding the feelings of others) and sympathy (empathic care for others). As Dan Zahavi explained, while in emotional contagion a feeling, which is a copy of moods and emotional states of other people, is regarded by the self as their own, "in empathy and sympathy, the experience you empathically understand or sympathetically care for remains that of the other. In both of the latter cases, the focus is on the other, the distance between self and other is preserved and upheld" (Zahavi, 2010: 179). In this way, MerleauPonty is discredited in his criticism of Scheler when he argues that in order to experience the other, Scheler destroys the deepest differences between the Self and the Other (see Merleau-Ponty, 1964: 174). In fact, despite that Scheler at some point actually describes emotional identification as metaphysical unity of all organic life, elsewhere he emphasises that the existence of this unity by no means removes the absolute difference between individuals (Zahavi, 2010: 185).

Nonetheless, we must be careful before we identify too hastily Scheler's concept of emotional identification with a positive meaning given to this term by Girard. In fact, Scheler's understanding of emotional identification is rather ambiguous, both positive and negative. It often takes the forms oscillating between the attitude of master and slave, as in the case of an idiopathic (when the other's being is completely absorbed by the self) or heteropathic (when the self's being is absorbed by the other) relationship. In both cases, the emerging "sense of unity" oppresses and emotionally erases another person. Emotional identification may also take other dangerous forms - orgiastic Dionysian mysteries, hypnosis, mental dissociation of consciousness, sadomasochism and violent movements of the masses. In addition, war itself is a condition in which people and groups give expression to their sense of unity.

However, exploring the multiplicity of empirical examples of emotional identification, Scheler discovers that the very sense of unity, which includes a dangerous 
tendency toward violence and domination, can also develop in the direction of positive forms of sympathy and love, and Stendhalian characters give testimony to this truth. When their relationships are purged of the temptation of idiopathic and heteropathic eroticism, and when the experience of being together in a common stream life prevails over the pursuit of the sympathetic takeover of the power (being) of another person, then they experience real passion, real l'amour passion (Scheler, 2008: 35f.). Heroically rising above desire in the form of self-gratifying lust while not idealising someone else's psychic individuality, they reach the third dimension, the right distance from which they can see each other rooted in the unity of life.

In general, Scheler devoted the whole first part of The Nature of Sympathy to releasing sympathy and love from pathological, idio- and hetreopathic manifestations of identification, which often exhibit symptoms similar to Girard's ontological disease. Passionate love does not belong to any of these categories; it rather involves a relationship between two independent human beings who found the highest value and fulfilment in living one life. ${ }^{4}$ This is what Stendhal describes with the language of literature-namely, the moment of releasing true passion from entanglement in a network of metaphysical desire - he describes it with the language of phenomenology of intersubjectivity. He reminds us that in our dealing with our loved ones we often behave as if we wanted to take over and absorb them into our own Self, not seeing that in this way we give vent to our metaphysical selfishness. We are misled by assuming that we are opening our hearts to the Other; in reality, we are merely compromising their autonomy. True l'amour passion opens us up to the value of life of the Other, living the same life as I do, thus establishing this relationship anew and removing the danger of mutual violence.

\section{St. Francis' Passionate Christianity}

In Batlling to the End Girard calls, both Hölderlin and Stendhal, "exceptional individuals" or even saints (Girard \& Chantre, 2010: 132). He sees their sainthood in their gift of explicating mimetic behaviour. In acknowledging the similarities, he sees no difference between the sanctity of both, which Scheler is able to realise. While Hölderlin is the saint of spirit, Stendhal is the saint of life. For the former, withdrawal from the world is a way to renew the harmony of Spirit. For the latter it provides a path to regain the harmony of life in passionate engagement with the world. But Scheler does not present these two orders as the elements of a radical alternative. Rather than telling us to choose between one and the other, he is attempting something else. He is trying to bridge the chasm between Spirit and

\footnotetext{
4 Such interpretation would be consistent with what the translators wrote in the introduction to the English edition of On Love: "Stendhal's ideal of love has various names: it is generally "passion-love," but more particularly 'love à l'italienne'. The thing in itself is always the same-it is the love of a man and a woman, not as husband and wife, not as mistress and lover, but as two human beings, who find the highest possible pleasure, not in passing so many hours of the day or night together, but in living one life. Still more, it is the attachment of two free fellow-creatures-not of master and slave" (Stendhal, "Introductory Preface to the Translation," in On love 1920: vi).
} 
Life by a double movement: spiritualisation of life through the personification of vital being and revival of spirituality. He accomplishes this by defining spirituality, not as opposed to vitality, but as associated with vitality and expressed in life. ${ }^{5}$ Not abolishing the differences between these two realms of existence, he adds that between Life and Spirit there is real "dynamic causality" (Scheler, 2008: 76). The same dynamism and the same relation also occurs between passionate love and charity, eros and agape: "Thus among all the forms of sympathy and varieties of love, the sense of vital unity with the cosmos stands, so to speak, at the opposite pole to the non-cosmic love of persons, founded upon the love of God. All the other forms lie, as it were, in stages between them. Those who seek to ascend this scale will surely fall if they insist upon taking the second step before they have made the first" (Scheler, 2008: 129).

Recognising this dynamic relationship between the spirit and life, according to Scheler, is nothing new to Christianity. Indeed, the tendency to elevate the spirit in the heart of Christianity has always been dominant, and Girard also succumbs to this tendency, especially after the apocalyptic turn in his career. But a tendency appreciating the spheres of life and vitality has also developed next to it and can be observed, for example, in the symbolism associated with the sacraments, in kenosis and the incarnation of Christ, in Christ's life, death and resurrection. Devotional experience of Passion, present in all Christian churches, is not just a commemoration of the Crucifixion or "compassion" in suffering with Jesus, but also genuine identification with the living Christ. Also developed from the very beginning, the imitatio Christi theme and St. Paul'swords- “it is no longer I who live, but Christ lives in me" (Gal 2, 20)—contain the idea of such identification.

Nevertheless, early Christianity had a tendency to underestimate the vitality present in human existence, and to overly focus on the purely spiritual dimension of our being. The emphasis of historic Christianity on the dignity of a spiritual person, which undoubtedly greatly contributed to the development of civilization and the history of mankind, simultaneously led to the devaluation of the vital sphere, and consequently to the disintegration of life. As a result, anyone who demonstrated emotional attachment to nature was considered "pagan". The logical trajectory of this is that nature, including body and everything associated with it, become obstacles on the way to true communion with God. The emphasis on the spirit fighting with the body, resulted in a strong distinction between the spiritual and vital soul in St. Augustine and other Church Fathers, as if the body and nature were a place of exceptional sinfulness, recognition of the sexual act as a form of inheritance of

\footnotetext{
5 The Nature of Sympathy has deep anthropological and ontological grounds. Scheler describes various forms of sympathy and empathy at numerous levels of the ontological structure of human existence. On a more basic vital level, human beings are guided by various impulses, desires and aspirations, fulfilling their vital functions. Thus, we demonstrate aspirations specific to living organisms. Our centre responsible for mental and vital functions constantly stimulates in us the desire for constant flowering, multiplication of life and active participation in elan vital. But man is also able to rise above their corporeal and vital essence, to the heights of spiritual existence. So aspirations that flow from our spirit have little in common with our vital and mental being.
} 
original sin, exaggerated ascetic techniques subjugating the vital impulses by punishing the body. This focus led to devaluation of life vitality throughout Christian thought.

But along with the franciscan movement, completely new values appear. St. Francis of Assisi, in contrast to the accepted metaphysical tradition, performed a profound "heresy of the heart" (Scheler, 2008: 87), by uniting the spirit and life in a single image of human existence. Expanding the scope of brotherly love to all living beings, Francis shows that all creatures are directly connected with the Creator and that the cosmos is filled with our "brothers and sisters" who are therefore also Father's children. In the eyes of Francis, the whole life is seen as divine, the whole creation participates in the Holy Communion with God and in God.

Scheler's reading of St Francis life is of special relevance for phenomenology of intersubjectivity, and for mimetic theory as well. Franciscanism involves a combination of two kinds of love, cosmic love for the world and life, and a cosmic love for neighbour and God. On the one hand, by transferring erotic and passionate love-so characteristic of the Provencal troubadours who exerted an enormous influence on him in his youth - to the least of our brothers and sisters, Francis' living love extends well beyond the spiritual beings and covers the whole of the pulsating life of the cosmos. At the same time, the "sublimation" of erotic emotions and intensification of brotherly love take place. That's why the intermingling of two types of love, eros and agape, the highest forms of life and spirit, not only makes Francis a Christian saint but also leads to a greater fullness of life than would be possible without this connection that he makes. Passionate eros directs its agapic love to all living creatures, and agape manifests itself in a deeper, richer experience of life, thanks to the opening of eros to the spiritual order of charity. As Scheler writes in Ressentiment: "When Francis of Assisi kisses festering wounds and does not even kill the bugs that bite him, but leaves his body to them as a hospitable home, these acts (if seen from the outside) could be signs of perverted instincts and of a perverted valuation. But that is not actually the case. It is not a lack of nausea or a delight in the pus which makes St. Francis act in this way. He has overcome his nausea through a deeper feeling of life and vigour! This attitude is completely different from that of recent modern realism in art and literature, the exposure of social misery, the description of little people, the wallowing in the morbid - a typical ressentiment phenomenon. Those people saw something bug-like in everything that lives, whereas Francis sees the holiness of 'life' even in a bug" (Scheler, 1998: 77f.).

\section{Conclusion}

From these two perspectives, an important lesson emerges. While Girard's apocalyptic spirituality allows us to better understand that in "absence and silence" God reveals his face, Scheler's panentheism gives hope for restoring the world, but also restoring divine spirit to the immanence of the world. This experience of "powerlessness of God", and this attentiveness to divine presence in our everyday life give rise to-what I would call after Richard Kearney - a certain kind of "ethics of kenosis" (Kearney, 2010: 133-137). Existing beyond all totalism, 
the ethics of kenosis emphasises the ideas of pluralism and multiplicity of human vocations to serve the weak, the poor, and the downtrodden.

But we need not draw too deep and far-reaching conclusions from Girard's mimetic theory and Scheler's phenomenology in order to gain important knowledge for our times. From the collision of their respective approaches, we attain a sufficiently broad perspective to answer the question: what is the proper (Christian or non-Christian) attitude to a world that is suffering contagion of mimetic rivalry and violence? Girard proposes a kind of "lock-down" solution to the pandemic. He exhorts us to imitate his featured saint Hölderlin in withdrawing from a violent world in order to limit the expansion of contagion. Scheler on the other hand exhorts to follow Saint Francis in his loving and active commitment to the world. For our world to survive, for healing our inter-human relationships, we are called to reasonable choose between that both attitudes that are equally important and valuable. During the pandemic, when we have to keep social distance and empathically care for those who suffer an illness, both approaches may exist in the world. Within these alternatives, there is a multiplicity of possibilities to realize the divine love in our ordinary universe. But to do so, our shared responsibility is required. As St. Paul teaches: "Let each has his eye on not only his own salvation, but also others. Have this mind among yourselves, which is yours in Christ Jesus (Phil 2: 4f.)". The Christian principle of solidarity precisely implies that others share responsibility for us, as we do for them. Sometimes, others can help us find and realise our responsibility, much better than we do (see Scheler, 1973: 104f.).

This equivalent of mutual and self-responsibility finds its prototype in the idea of the church as the corpus Christianum. Solidary impact of individual persons on the salvation of a single person and the impact of the individual on the salvation of all others is the essence of the Church's activities. But in its ecclesiology - as Ann Astell (2017: 410f.) pointed out-Church cannot forget that, although founded on Christ, the once rejected "cornerstone" (Eph 2:20), it is built of "living stones" (1 Peter 2.5). As "a living organism" it is always exposed to the temptation to express its vitality through domination and violence, temptation to which it has succumbed often in its history. There is a deep truth in the statement of Hannah Arendt that people, setting things in motion, are not always able to predict the consequences of their own initiatives, and what is worse, they are also unable to reverse them (see Arendt, 1998: 236-247). Frequently, the results of action are significantly different from the plans, and any action invites unknown initiatives intruding into the public sphere. In spite of such risks, this human reality should neither paralyse human potential nor sentence humans to a radical passivity. The tensions tormenting the world today will increase if we remain deaf to the call for responsibility.

Acknowledgements I would like to thank anonymous reviewers for their relevant comments, which helped me to revise this article. I am also grateful to Anthony Bartlett, Charles Mabee and Thomas Ryba, for their attentive reading and all helpful remarks.

Open Access This article is licensed under a Creative Commons Attribution 4.0 International License, which permits use, sharing, adaptation, distribution and reproduction in any medium or format, as long 
as you give appropriate credit to the original author(s) and the source, provide a link to the Creative Commons licence, and indicate if changes were made. The images or other third party material in this article are included in the article's Creative Commons licence, unless indicated otherwise in a credit line to the material. If material is not included in the article's Creative Commons licence and your intended use is not permitted by statutory regulation or exceeds the permitted use, you will need to obtain permission directly from the copyright holder. To view a copy of this licence, visit http://creativecommons.org/licenses/by/4.0/.

\section{References}

Arendt, H. (1998). Human condition. University of Chicago Press.

Astell, A. (2004). Saintly mimesis, contagion, and empathy in the thought of René Girard, Edith Stein, and Simone Weil. Shofar: A Journal of Jewish Studies, 22(2), 116-131.

Astell, A. (2017). Violence, mysticism, and René Girard. Theological Studies, 78(2), 389-411.

Blasi, L. D. (2015). Within and Beyond Mimetic Desire. In P. Aantonello \& H. Webb (Eds.), Mimesis, desire and the novel: René Girard and literary criticism (pp. 39-53). Michigan State University Press.

Bonhoeffer, D. (1971). Letters and papers from prison. Simon and Schuster.

Dumouchel, P. (2015). The barren sacrifice: An essay on political violence. Michigan State University Press.

Dupuy, J.-P. (2002). Pour un catastrophisme éclairé: quand l'impossible est certain. Seuil.

Girard, R. (1965). Deceit, desire, and the novel; self and other in literary structure. Johns Hopkins Press.

Girard, R. (1977). Violence and the sacred. Johns Hopkins University Press.

Girard, R. (1986). The scapegoat. Johns Hopkins University Press.

Girard, R. (2008). Valéry and Stendhal. In R. Doran (Ed.), Mimesis and theory: Essays on literature and criticism, 1953-2005 (pp. 13-25). Stanford University Press.

Girard, R., \& Chantre, B. (2010). Battling to the end: conversations with Benoit Chantre. Michigan State University Press.

Girard, R., Oughourlian, J.-M., \& Lefort, G. (1987). Things hidden since the foundation of the world. Stanford University Press.

Girard, R., \& Treguer, M. (2014). When these things begin: Conversations with Michel Treguer. Michigan State University Press.

Holzhey, C. F. E. (2015). Recantation without conversion: Desire, mimesis, and the Paradox of Engagement in Pier Paolo Pasolini's Petrolio. In P. Antonello \& H. Webb (Eds.), Mimesis, desire and the novel: René Girard and literary criticism (pp. 39-53). Michigan State University Press.

Kearney, R. (2010). Anatheism: returning to God after God. Columbia University Press.

Merleau-Ponty, M. (1964). Signs. Northwestern University Press.

Palaver, W. (2013). René Girard's mimetic theory. India: Michigan State University Press.

Pascal, B., Trotter, W. F., Booth, M. L., \& Wight, O. W. (1910). Thoughts. P.F. Collier \& son.

Scheler, M. (1973). Ordo Amoris. In D. R. Lachterman (Ed.), Selected philosophical essays (pp. 98-135). Northwestern University Press.

Scheler, M. (1998). Ressentiment. Marquette University Press.

Scheler, M. (2008). The nature of sympathy. Transaction Publishers.

Schwager, R. (2006). Banished from Eden: Original sin and evolutionary theory in the drama of salvation. Gracewing.

Scubla, L. (2016). Giving life, giving death: Psychoanalysis, anthropology, philosophy. India: Michigan State University Press.

Stendhal (1920). Introductory preface to the translation. In On love. Plymouth: The Mayflower Press.

Vandenberghe, F. (2008). Sociology of the heart: Max Scheler's epistemology of love. Theory, Culture \& Society, 25(3), 17-51.

Zahavi, D. (2010). Max Scheler. In K.A.-P.A. Schrift (Ed.), The history of continental philosophy (pp. 171-186). Acumen Press.

Publisher's Note Springer Nature remains neutral with regard to jurisdictional claims in published maps and institutional affiliations. 